\title{
PEMANFAATAN KOTORAN SAPI DAN PUPUK NPK YARA-MILA 16-16-16 \\ TERHADAP PERTUMBUHAN DAN PRODUKSI TANAMAN KACANG PANJANG (Vigna sinensis L.)
}

\section{UTILIZATION OF COW MANURE AND NPK YARA-MILA 16-16-16 OF FERTILIZER ON THE GROWTH AND PRODUCTION OF LONG BEANS (Vigna sinensis L.)}

\author{
Murdhiani $^{1}$, Rina Maharany ${ }^{2}$ \\ ${ }^{1}$ Program Studi Agroekoteknologi, Fakultas Pertanian UNSAM, Langsa Aceh. \\ Meurandeh-Langsa aceh, Telp (0641)426487, Fax (0641)7445137 \\ ${ }^{2}$ Program Studi Budidaya Perkebunan, STIPER Agrobisnis Perkebunan Medan. \\ Jalan Willem Iskandar, Pancing Medan Estate 20000 \\ E-mail : rina_maharany@stipap.ac.id
}

\begin{abstract}
ABSTRAK
Permintaan kacang panjang meningkat setiap tahunnya, sementara produksi belum dapat memenuhi permintaan pasar. Peningkatkan hasil tanaman kacang panjang dapat dilakukan secara intensifikasi dengan pemberian pupuk organik dan pupuk anorganik secara tepat. Penelitian ini menggunakan Rancangan Acak Kelompok (RAK) Faktorial yang terdiri dari 2 faktor, yaitu pemberian kotoran sapi dengan 4 taraf, yaitu : $\mathrm{K}_{0}=0 \mathrm{~kg} / \mathrm{ha}$ (kontrol), $\mathrm{K}_{1}=$ 10 ton/ha $(2,88 \mathrm{~kg} / \mathrm{plot}), \mathrm{K}_{2}=15$ ton $/ \mathrm{ha}(4,32 \mathrm{~kg} / \mathrm{plot}), \mathrm{K}_{3}=20$ ton $/ \mathrm{ha}(5,76 \mathrm{~kg} / \mathrm{plot})$ dan pemberian pupuk NPK Yara-Mila 16-16-16 dengan 3 taraf, yaitu : $\mathrm{Y}_{\mathrm{o}}=0 \mathrm{~kg} / \mathrm{ha}$ (kontrol), $\mathrm{Y}_{1}$ $=15 \mathrm{~kg} / \mathrm{ha}(43,2 \mathrm{~g} / \mathrm{plot}), \mathrm{Y}_{2}=300 \mathrm{~kg} / \mathrm{ha}(86,4 \mathrm{~g} / \mathrm{plot})$. Parameter yang diamati; tinggi tanaman, jumlah daun, umur berbunga tanaman, produksi per tanaman dan produksi per plot. Hasil penelitian menunjukkan bahwa pemberian pupuk kandang kotoran sapi berpengaruh nyata terhadap jumlah daun umur 2 minggu setelah tanam (MST) dan berpengaruh sangat nyata terhadap tinggi tanaman umur 2, 4 dan $6 \mathrm{MST}$, dan produksi per plot. Jumlah daun terbanyak umur 2 MST adalah 8.44 helai pada perlakuan $\mathrm{K}_{3}$. Tinggi tanaman yang tertinggi umur $6 \mathrm{MST}$ adalah $230.87 \mathrm{~cm}$ pada perlakuan $\mathrm{K}_{3}$. Produksi per plot terberat adalah $2.97 \mathrm{~kg}$ pada perlakuan $\mathrm{K}_{3}$. Pemberian pupuk NPK Yara-Mila 16-16-16 berpengaruh nyata terhadap tinggi tanaman umur 4 dan 6 MST. Tinggi tanaman yang tertinggi umur 6 MST adalah 218.64 $\mathrm{cm}$ pada perlakuan $\mathrm{Y}_{2}$. Interaksi antara kedua perlakuan menunjukkan berpengaruh nyata terhadap jumlah daun umur $4 \mathrm{MST}$, yaitu 16.93 helai pada perlakuan $\mathrm{K}_{1} \mathrm{Y}_{1}$.
\end{abstract}

Kata Kunci : Kotoran Sapi, Pupuk NPK Yara-Mila, hasil

\section{ABSTRACT}

The demand for a long bean increases every year, while the production cannot meet market demand. To increase the yield of long bean plants can be cultivated by optimizing both organic fertilizers and inorganic fertilizers. This study used a factorial randomized block design (RBD) consisting of 2 factors, namely the provision of cow dung with 4 levels, namely: $\mathrm{K} 0=0 \mathrm{~kg} / \mathrm{ha}, \mathrm{K} 1=10$ tons $/ \mathrm{ha}(2.88 \mathrm{~kg} / \mathrm{plot}), \mathrm{K} 2=15$ tons $/ \mathrm{ha}(4.32 \mathrm{~kg} / \mathrm{plot}), \mathrm{K} 3$ $=20$ tons $/$ ha $(5.76 \mathrm{~kg} / \mathrm{plot})$ and the application of Yara-Mila NPK fertilizer 16-16-16 with 3 levels, namely: Yo $=0 \mathrm{~kg} / \mathrm{ha}$ (kontrol), Y1 $=15 \mathrm{~kg} / \mathrm{ha}(43.2 \mathrm{~g} / \mathrm{plot}), \mathrm{Y} 2=300 \mathrm{~kg} / \mathrm{ha}(86.4$ $\mathrm{g} /$ plot). Observation of parameters plant was; height, number of leaves, age of flowering 
plants, long bean yield. The results showed that fertilizer given of cow manure had a significant effect on the number of leaves at 2 weeks after planting (WAP) and significantly affected yield and plant height at 2, 4 and 6 weeks after plant. The highest number of leaves at 2 WAP the plant was 8.44 strands in K3 treatment. The highest of plant height at 6 WAP the plant was $230.87 \mathrm{~cm}$ in $\mathrm{K} 3$ treatment. The heaviest production per plot is $2.97 \mathrm{~kg}$ for K3 treatment. The administration of Yara-Mila NPK 16-16-16 significantly affected plant height at ages 4 and 6 WAP. The highest plant height at age $6 \mathrm{MST}$ was $218.64 \mathrm{~cm}$ in the Y2 treatment. The interaction between the two treatments showed a significant effect on the number of leaves aged 4 weeks after plant, ie 16.93 strands in the K1Y1 treatment.

Keywords ; Cow Manure, Yara-Mila NPK, Production, Long Beans

\section{PENDAHULUAN}

Kebutuhan sayuran semakin meningkat seiring dengan semakin meningkatnya kepedulian masyarakat terhadap pola hidup dan makanan yang sehat dan berimbang. Data konsumsi kacang panjang di Sumatera utara pada tahun 2014 yang diperkirakan sebesar 2,66 $\mathrm{kg} / \mathrm{kapita} / \mathrm{tahun}$, dengan demikian diperlukan kacang panjang sebanyak 492.000 ton/tahun (BPS, 2014). Akan tetapi, berdasarkan data BPS (2014), produktivitas kacang panjang tahun 2013 baru mencapai 450.859 ton/tahun. Untuk itulah sangat diperlukan usaha-usaha yang dapat meningkatkan produksi tanaman kacang panjang, salah satunya adalah dengan penambahan unsur hara yang dapat bersumber dari pupuk organik atau anorganik.

Pupuk organik yang dapat digunakan antara lain kotoran sapi, karena banyak mengandung air dan lendir. Dalam keadaan demikian, peranan jasad renik mampu untuk mengubah bahan organik yang terkandung dalam pupuk menjadi zatzat hara yang dalam bentuk tersedia dalam tanah seperti unsur hara Nitrogen, serta mencukupi keperluan pertumbuhan dan meningkatkan produksi tanaman seperti jenis tanaman kacang panjang. Berdasarkan hasil penelitian (Thomas et al., 2017), kebutuhan kotoran sapi untuk tanaman kacang panjang adalah sebesar 10 ton/ha.

Sementara itu, salah satu jenis pupuk anorganik yang lazim digunakan untuk memenuhi unsur hara dalam tanah adalah pupuk NPK. Menurut Fahmi (2014), pupuk NPK Yara-Mila (16:16:16) merupakan salah satu pupuk anorganik bersifat majemuk yang memiliki unsur hara makro $\mathrm{N}$, $\mathrm{P}$, dan $\mathrm{K}$ masing-masing $16 \%$, dan mudah diserap tanaman karena unsur $\mathrm{N}$ sebagian besar dalam bentuk ion $\mathrm{NO}_{3}{ }^{-}$dan $\mathrm{NH}_{4}{ }^{-}$. Nitrogen merupakan unsur mobile di dalam tanah, oleh karena itu unsur $\mathrm{N}$ sangat dibutuhkan bagi tanaman selain menambah kesuburan tanah juga meningkatkan hasil produksi tanaman khususnya tanaman kacang-kacangan.

\section{METODE PENELITIAN}

Penelitan ini dilaksanakan di Desa Tanjung Asri, Kecamatan Sei Dadap, Kabupaten Asahan, Provinsi Sumatera Utara dengan topografi datar dan ketinggian tempat $13 \mathrm{~m}$ di atas permukaan laut (dpl). Penelitian ini dilaksanakan dari bulan Mei sampai Juli 2015.

Alat yang digunakan dalam penelitan ini antara lain cangkul, garu, parang babat, gembor, ember, handsprayer, meteran, gergaji, palu, papan dan alat tulis. Sedangkan bahan yang digunakan dalam penelitian ini antara lain benih kacang panjang varietas hijau super, kotoran sapi, pupuk NPK Yara-Mila 1616-16, fungisida Dithane M-45 0,2\%, insektisida Curacron EC $0,2 \%$, air dan lain-lain.

Penelitian ini menggunakan Rancangan Acak Kelompok (RAKF) Faktorial, yang terdiri dari 2 faktor yaitu : 
1. Pemberian kotoran sapi $(\mathrm{K})$ terdiri dari 4 taraf:

$\mathrm{K}_{0} \quad: 0$ ton $/ \mathrm{ha} \quad=0 \mathrm{~kg} / \mathrm{plot}$

$\mathrm{K}_{1} \quad: 10 \mathrm{ton} / \mathrm{ha}=2,88 \mathrm{~kg} / \mathrm{plot}$

$\mathrm{K}_{2}: 15 \mathrm{ton} / \mathrm{ha}=4,32 \mathrm{~kg} / \mathrm{plot}$

$\mathrm{K}_{3} \quad: 20$ ton $/ \mathrm{ha} \quad=5,76 \mathrm{~kg} / \mathrm{plot}$

2. Pemberian pupuk NPK Yara-Mila 16-

16-16 (Y) terdiri dari 3 taraf :

$\mathrm{Y}_{0} \quad: 0 \mathrm{~kg} / \mathrm{ha}=0 \mathrm{~g} / \mathrm{plot}$

$\mathrm{Y}_{1} \quad: 150 \mathrm{~kg} / \mathrm{ha}=43,2 \mathrm{~g} / \mathrm{plot}$

Y2 $: 300 \mathrm{~kg} / \mathrm{ha}=86,4 \mathrm{~g} / \mathrm{plot}$

Pengujian parameter disusun pada daftar sidik ragam dan dilakukan uji jarak berganda Duncan dengan taraf 5\% .

Tahapan penelitian dilaksanakan sebagai berikut :

$>$ Persiapan Lahan dan Pembuatan Plot Penelitian

Areal yang akan digunakan sebagai lahan penelitian sebaiknya dibersihkan terlebih dahulu dari gulma, kayu, batu-batuan dan kotoran-kotoran lainnya, sehingga terhindar dari sumber hama dan penyakit tanaman. Pengolahan tanah dilakukan dengan mencangkul tanah hingga tanah menjadi gembur, lebar plot tanaman $160 \mathrm{~cm} \mathrm{x} 180 \mathrm{~cm}$, tinggi plot $\pm 30 \mathrm{~cm}$, dengan jarak tanam 30 x $40 \mathrm{~cm}$.

$>$ Pemberian Pupuk Kandang Kotoran Sapi

Pemberian pupuk kandang kotoran sapi dilakukan 2 minggu sebelum tanam dengan cara mencampurkannya secara merata dengan tanah sesuai dengan dosis perlakuan yang telah di tentukan.

\section{$>$ Penanaman Benih}

Penanaman dilakukan 2 minggu setelah pemberian pupuk kandang kotoran sapi, benih dapat langsung ditanam dilahan yang sudah ditentukan. Benih ditanam dengan jarak tanam 30 x $40 \mathrm{~cm}$.

$>$ Aplikasi Pupuk NPK Yara-Mila 1616-16
Pemberian pupuk NPK Yara-Mila 16-16-16 diberikan 3 kali dari dosis yang diaplikasikan (sesuai perlakuan masing-masing) yaitu taburan awal diberikan pada saat 0 , 2 dan 4 minggu setelah tanam. Pupuk ditaburkan secara merata dengan cara melingkar $\pm 15 \mathrm{~cm}$ di sekitar batang tanaman.

$>$ Panen

Panen merupakan salah satu tahap dalam proses produksi yang akan mempengaruhi hasil dan kualitas. Ciri kacang panjang yang siap dipanen adalah kacang panjang yang mudah dipatahkan dan bijibiji didalam polongnya tidak menonjol. Waktu panen terbaik adalah pada pagi hari (pukul 07:0010:00 WIB) dan sore hari (pukul 16:00-18:00 WIB). Cara pemanenannya dengan cara memotong tangkai buah dengan pisau atau gunting. Tanaman kacang panjang dapat dipanen setelah umur $2-3$ bulan.

Parameter pengamatan dalam penelitian ini adalah tinggi tanaman (cm), jumlah daun (helai), umur berbunga kacang panjang (hari), produksi per tanaman sampel $(\mathrm{g})$, produksi tanaman per plot $(\mathrm{kg})$.

\section{HASIL DAN PEMBAHASAN}

Dari hasil pengamatan dan analisis sidik ragam dapat dilihat bahwa pemberian pupuk kandang kotoran sapi berpengaruh sangat nyata terhadap tinggi tanaman pada umur 2, 4 dan 6 minggu setelah tanam (MST). Pemberian pupuk NPK Yara-Mila 16-16-16 menunjukkan berpengaruh nyata pada umur 4 dan 6 minggu setelah tanam (MST). Sedangkan interaksi antara pemberian pupuk kandang kotoran sapi dan pupuk NPK Yara-Mila 16-16-16 menunjukkan tidak berpengaruh nyata terhadap tinggi tanaman kacang panjang. 
Tabel 1. Hasil Uji Beda Rataan Pengaruh Pemberian Pupuk Kandang Kotoran Sapi dan Pupuk NPK Yara-Mila 16-16-16 Terhadap Tinggi Tanaman Kacang Panjang Pada Umur 6 Minggu Setelah Tanam (MST).

\begin{tabular}{ccccc}
\hline Perlakuan & $\mathbf{Y}_{\mathbf{0}}$ & $\mathbf{Y}_{\mathbf{1}}$ & $\mathbf{Y}_{\mathbf{2}}$ & Rataan \\
\hline $\mathbf{K}_{\mathbf{0}}$ & 115.56 & 179.61 & 191.12 & $162.10 \mathrm{c}$ \\
$\mathbf{K}_{\mathbf{1}}$ & 175.27 & 194.40 & 214.59 & $194.75 \mathrm{~b}$ \\
$\mathbf{K}_{\mathbf{2}}$ & 196.67 & 195.83 & 219.94 & $204.15 \mathrm{~b}$ \\
$\mathbf{K}_{\mathbf{3}}$ & 221.83 & 221.87 & 248.91 & $230.87 \mathrm{a}$ \\
\hline Rataan & $177.33 \mathrm{~b}$ & $197.93 \mathrm{a}$ & $218.64 \mathrm{a}$ & $\mathrm{KK}=17.18 \%$ \\
\hline
\end{tabular}

Keterangan : Angka-angka yang diikuti oleh huruf yang sama pada kolom yang sama untuk setiap perlakuan tidak berbeda nyata menurut uji duncan pada taraf $5 \%$.

Dari Tabel 1 dapat dilihat bahwa pemberian pupuk NPK Yara-Mila 16-1616 dengan perlakuan 86,4 g/plot $\left(\mathrm{Y}_{2}\right)$ memiliki tinggi tanaman tertinggi yaitu 218,64 cm, sedangkan tinggi tanaman terendah yaitu $177,33 \mathrm{~cm}$, terdapat pada perlakuan 0 g/ plot $\left(\mathrm{Y}_{0}\right)$. Sementara pemberian pupuk kandang kotoran sapi dengan perlakuan $5,76 \mathrm{~kg} /$ plot $\left(\mathrm{K}_{3}\right)$ memiliki tinggi tanaman tertinggi yaitu 230,87 cm, sedangkan tinggi tanaman terendah yaitu $162,10 \mathrm{~cm}$, terdapat pada perlakuan $0 \mathrm{~kg} /$ plot $\left(\mathrm{K}_{0}\right)$.

Adanya pengaruh nyata dari pemberian pupuk NPK Yara-Mila 16-1616 terhadap tinggi tanaman umur 4 dan 6 minggu setelah tanam (MST) disebabkan oleh unsur hara yang terdapat dalam pupuk NPK merupakan unsur hara cepat tersedia sehingga sudah dapat diserap dengan baik oleh tanaman, yaitu unsur hara $\mathrm{N}$ yang lebih cepat terserap untuk membantu proses pertumbuhan vegetatif tanaman. Tinggi tanaman pada umur 4 dan 6 minggu setelah tanam (MST) menunjukkan pengaruh yang nyata dengan adanya peningkatan dosis pupuk NPK Yara-Mila. Semakin meningkat dosis pupuk, maka terjadi kenaikan pertumbuhan tinggi tanaman, hal ini disebabkan bahwa dengan semakin dewasanya tanaman, maka sistem perakaran telah berkembang dengan baik dan lengkap, sehingga tanaman semakin mampu menyerap unsur hara dalam bentuk anion dan kation yang mengandung unsur $\mathrm{N}$, P dan $\mathrm{K}$ yang terdapat pada pupuk NPK Yara-Mila tersebut.
Dengan banyaknya unsur hara yang dapat diserap oleh tanaman, maka pertumbuhan dan perkembangan tanaman semakin meningkat. Bila dosis pupuk ditingkatkan, maka ada kecenderungan peningkatan pertumbuhan vegetatif dan generatif tanaman, sesuai dengan pendapat Hendri (2015), bahwa unsur hara $N$ diperlukan oleh tanaman untuk pembentukan klorofil, dan merangsang pertumbuhan vegetatif tanaman seperti batang, cabang, dan daun.

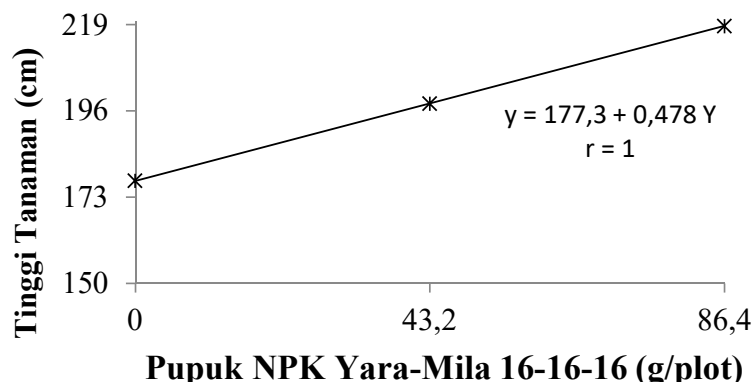

Gambar 1.Pengaruh Pemberian Pupuk NPK YaraMila Terhadap Tinggi Tanaman $(\mathrm{cm})$ Kacang Panjang pada Umur 6 Minggu Setelah Tanam (MST)

Gambar 1 menunjukkan bahwa pemberian pupuk NPK Yara-Mila memiliki garis linier positif yang berarti bahwa pemberian pupuk NPK Yara-Mila sejalan dengan peningkatan tinggi tanaman. Pemberian pupuk NPK YaraMila berpengaruh pada pertumbuhan tinggi tanaman dikarenakan unsur hara makro $\mathrm{N}$, $\mathrm{P}$, dan $\mathrm{K}$ yang cepat tersedia dan memiliki peran penting pada pertumbuhan vegetatif dan generatif tanaman. 
Unsur nitrogen yang diserap dalam bentuk $\mathrm{NO}_{3}{ }^{-}$direduksi dalam tanaman dan bergabung dengan senyawa organik menjadi asam amino yang kemudian membentuk protein yang menjadi subtrat dalam pembentukan dan pembelahan sel. Unsur $\mathrm{P}$ sebagai sumber energi yang membantu tanaman dalam perkembangan fase vegetatif. Unsur $\mathrm{K}$ mempunyai pengaruh dalam proses fisiologi antara lain ; pembelahan sel, formasi fotosintesis dari karbohidrat, reduksi nitrat dan mengubah hasil sintesis menjadi protein, aktifitas enzim, serta mengatur pergerakan stomata sehingga membantu pergerakan masuk keluarnya unsur ke dalam tanaman (Anonim, 2011). Nurnik (2012) juga menjelaskan bahwa tanaman akan tumbuh dengan suburnya, apabila segala hara yang dibutuhkan tanaman cukup tersedia, dan unsur hara itu ada dalam bentuk yang sesuai untuk diserap tanaman.

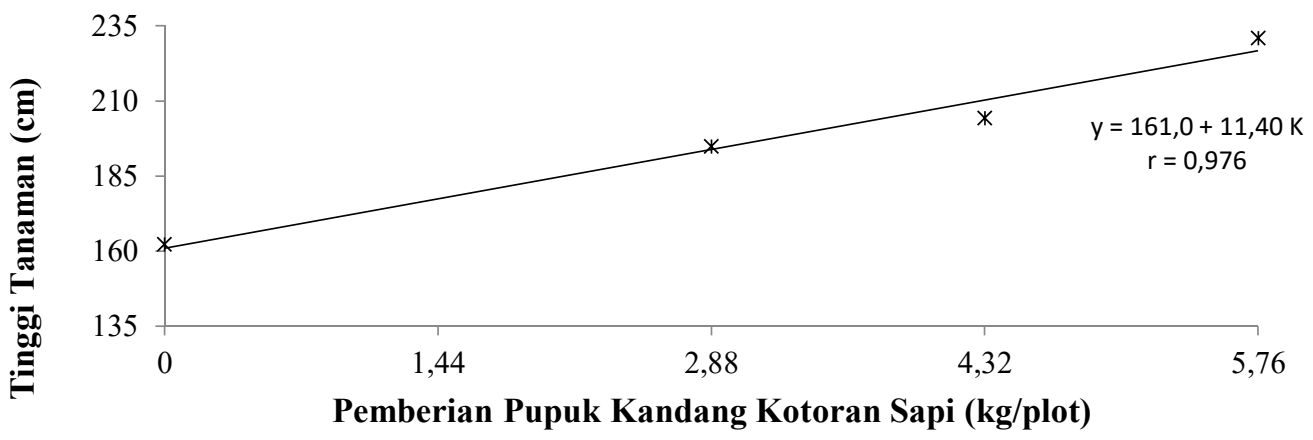

Gambar 2. Pengaruh Pemberian Pupuk Kandang Kotoran Sapi Terhadap Tinggi Tanaman (cm) Kacang Panjang Pada Umur 6 Minggu Setelah Tanam (MST)

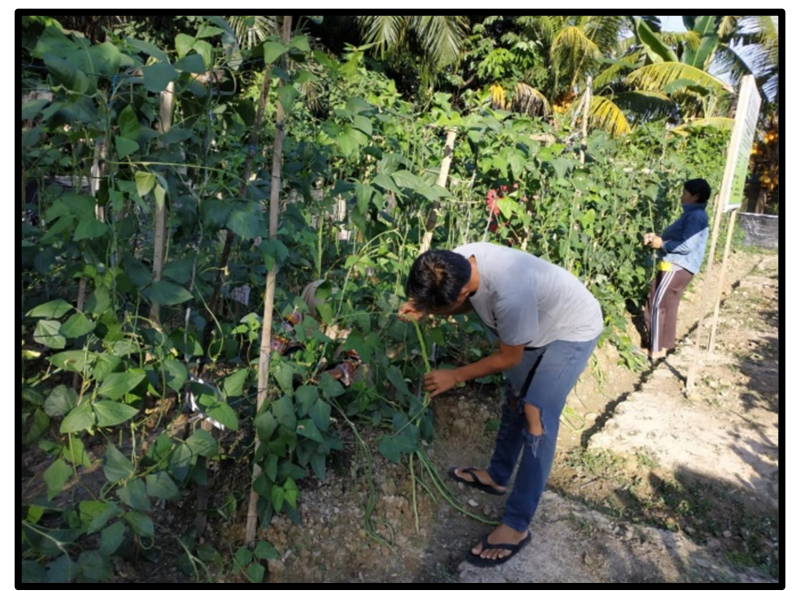

Gambar 3. Pengamatan Parameter Tinggi Tanaman dan Jumlah Daun Tanaman Kacang Panjang Pada Umur 6 Minggu Setelah Tanam (MST)

Gambar 2 menunjukkan bahwa pemberian pupuk kandang kotoran sapi memiliki garis linier positif yang berarti bahwa pemberian pupuk kandang kotoran sapi sejalan dengan peningkatan tinggi tanaman $(\mathrm{cm})$. Adanya pengaruh sangat nyata terhadap tinggi tanaman dikarenakan pemupukan tanah dengan pupuk kandang kotoran sapi dapat mengakibatkan tanah menjadi baik dengan daya mengikat airnya menjadi lebih tinggi. Hal ini sesuai dengan pendapat Arniana (2012), bahwa semakin banyak pupuk kandang yang diberikan berarti akan semakin banyak kadar hara yang dihasilkan dari hasil mineralisasi pupuk, yang dapat diserap oleh tanaman untuk meningkatkan pertumbuhan dan hasil tanaman kacang panjang. Menurut Jamin et al., (2013), bahwa kotoran sapi merupakan pupuk organik yang dapat memperbaiki kesuburan tanah, dan mempunyai unsur hara yang cukup untuk merangsang pertumbuhan tinggi tanaman dan mudah diserap oleh akar yang 
digunakan untuk proses penyusunan metabolisme di dalam tubuh tanaman.

Ketidakmampuan interaksi antara
kedua perlakuan pemberian pupuk kandang kotoran sapi dan pupuk NPK Yara-Mila disebabkan karena kandungan hara organik pada pupuk kandang bersifat lambat tersedia (slow release) sehingga belum dapat dimanfaatkan oleh tanaman. Pemberian pupuk organik yang relatif cepat dengan penanaman dapat menyebabkan nutrisi di dalamnya belum tersedia karena proses dekomposisi pupuk organik memerlukan proses dan waktu. Pada penelitian ini, pengaruh pupuk kandang kotoran sapi terhadap tanaman sangat lambat, sehingga pupuk NPK YaraMila berperan secara tunggal terhadap pertumbuhan dan produksi tanaman kacang panjang.

Pada kondisi apabila salah satu faktor tidak saling mendukung, maka interaksi kedua perlakuan yang diuji tidak mampu mempengaruhi sifat genetis yang dibawa oleh tanaman tersebut. Tanaman akan tumbuh baik bila ketersediaan hara pada tanah dalam keadaaan baik, seimbang, dan tersedia. Dalam arti faktor produksi yang lain seperti tanah dan iklim dalam kondisi optimal. Apabila terdapat dua faktor yang diteliti, sedangkan salah satu faktor dominan pengaruhnya

Tabel 2. Hasil Uji Beda Rataan Pengaruh Pemberian Pupuk Kandang Kotoran Sapi dan Pupuk NPK Yara-Mila 16-16-16 Terhadap Jumlah Daun Tanaman Kacang Panjang Umur 4 Minggu Setelah Tanam (MST).

\begin{tabular}{ccccc}
\hline Perlakuan & $\mathbf{Y}_{\mathbf{0}}$ & $\mathbf{Y}_{\mathbf{1}}$ & $\mathbf{Y}_{\mathbf{2}}$ & Rataan \\
\hline $\mathbf{K}_{\mathbf{0}}$ & $15.13 \mathrm{c}$ & $15.47 \mathrm{bc}$ & $15.53 \mathrm{~b}$ & $15.38 \mathrm{c}$ \\
$\mathbf{K}_{\mathbf{1}}$ & $15.73 \mathrm{~b}$ & $16.93 \mathrm{a}$ & $15.47 \mathrm{bc}$ & $16.04 \mathrm{a}$ \\
$\mathbf{K}_{\mathbf{2}}$ & $15.80 \mathrm{ab}$ & $15.53 \mathrm{~b}$ & $15.80 \mathrm{ab}$ & $15.71 \mathrm{~b}$ \\
$\mathbf{K}_{\mathbf{3}}$ & $16.20 \mathrm{ab}$ & $15.47 \mathrm{bc}$ & $16.53 \mathrm{a}$ & $16.07 \mathrm{a}$ \\
\hline Rataan & 15.72 & 15.85 & 15.83 & $\mathrm{KK}=3.82 \%$
\end{tabular}

Keterangan : Angka-angka yang diikuti oleh huruf yang sama pada kolom yang sama untuk setiap perlakuan tidak berbeda nyata menurut uji duncan pada taraf $5 \%$.

Data pada Tabel 2 terlihat bahwa interaksi perlakuan antara pemberian pupuk kandang kotoran sapi dengan pupuk NPK Yara-Mila memiliki jumlah daun tanaman terbanyak yaitu 16,93 helai terdapat pada perlakuan $\left(\mathrm{K}_{1} \mathrm{Y}_{1}\right)$ dengan dibandingkan faktor lainnya, maka faktor yang lemah akan tertutupi dan masingmasing faktor mempunyai sifat dan kerja yang berbeda dalam mendukung pertumbuhan tanaman. Hal ini sesuai dengan pendapat Nurhayati (2010), bahwa pertumbuhan tanaman yang baik dapat tercapai bila faktor yang mempengaruhi pertumbuhan berimbang dan menguntungkan.

Dari hasil analisis pengamatan dan analisis sidik ragam dapat dilihat bahwa pemberian pupuk kandang kotoran sapi menunjukkan pengaruh nyata terhadap jumlah daun pada umur 2 minggu setelah tanam (MST). Pemberian pupuk NPK Yara-Mila 16-16-16 menunjukkan tidak berpengaruh nyata terhadap jumlah daun pada umur 2, 4 dan 6 minggu setelah tanam (MST). Sedangkan interaksi antara pemberian pupuk kandang kotoran sapi dan pupuk NPK Yara-Mila 16-16-16 menunjukkan pengaruh nyata terhadap jumlah daun tanaman kacang panjang umur 4 minggu setelah tanam (MST). Hasil uji beda rataan pengaruh pemberian pupuk kandang kotoran sapi dan pupuk NPK Yara-Mila 16-16-16 terhadap jumlah daun tanaman kacang panjang umur 4 minggu setelah tanam (MST) dapat dilihat pada Tabel 2 : 


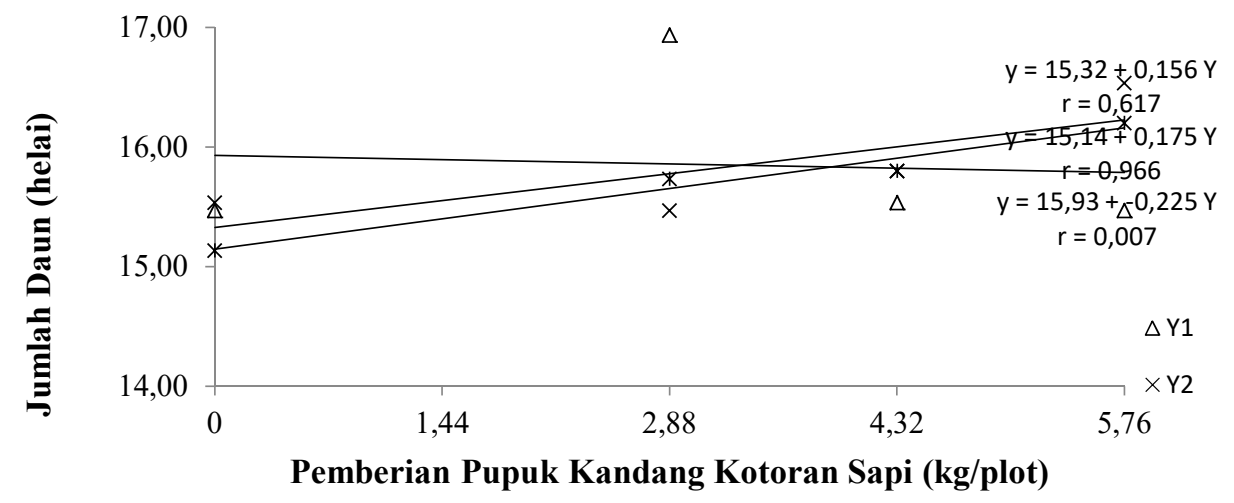

(a)

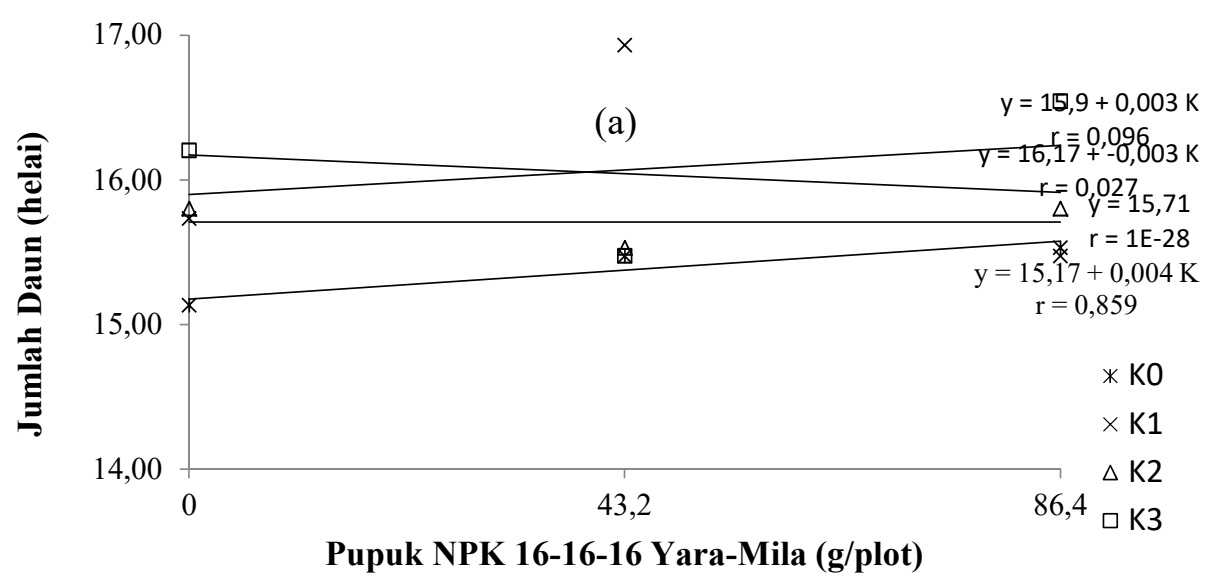

(b)

Gambar 4. (a) Pengaruh Pemberian Pupuk Kandang Kotoran Sapi Terhadap Jumlah Daun Tanaman (helai) Kacang Panjang pada Umur 2 MST, (b) Pengaruh Interaksi Antara Pemberian Pupuk Kandang Kotoran Sapi dan Pupuk NPK Yara-Mila Terhadap Jumlah Daun Tanaman (helai) Kacang Panjang pada Umur 4 MST.

Adanya pengaruh interaksi yang nyata dari kedua perlakuan terhadap parameter jumlah daun tanaman kacang panjang, dikarenakan pemberian pupuk NPK Yara-Mila mengandung hara utama essensial yang sangat dibutuhkan tanaman. Unsur hara tersebut sangat baik untuk pertumbuhan dan produksi tanaman, sehingga akan menyebabkan perbedaan yang sangat nyata dibandingkan dengan kontrol. Selain itu unsur hara yang tersedia juga cepat diserap oleh tanaman, dikarenakan sifat pupuk kimia yang mudah diserap dan diuraikan oleh tanaman. Dari hasil penelitian, peningkatan dosis pupuk NPK terlihat dapat meningkatkan pertumbuhan tanaman. Hal ini dikarenakan penambahan dosis pupuk NPK Yara-Mila akan meningkatkan kandungan hara makro dan mikro yang diserap tanaman, sehingga akan memacu metabolisme tanaman dan menyebabkan peningkatan pertumbuhan dan hasil yang sangat nyata.

Dari hasil analisis pengamatan dan analisis sidik ragam dapat dilihat bahwa pemberian pupuk kandang kotoran sapi maupun pupuk NPK Yara-Mila 16-16-16 menunjukkan tidak berpengaruh nyata terhadap umur berbunga tanaman kacang panjang. Sama halnya dengan interaksi antara pemberian pupuk kandang kotoran sapi dan pupuk NPK Yara-Mila 16-16-16 
juga menunjukkan tidak berpengaruh nyata

panjang.

terhadap umur berbunga tanaman kacang

Tabel 3. Hasil Uji Beda Rataan Pengaruh Pemberian Pupuk Kandang Kotoran Sapi dan Pupuk NPK Yara-Mila 16-16-16 Terhadap Umur Berbunga Tanaman Kacang Panjang.

\begin{tabular}{ccccc}
\hline Perlakuan & $\mathbf{Y}_{\mathbf{0}}$ & $\mathbf{Y}_{\mathbf{1}}$ & $\mathbf{Y}_{\mathbf{2}}$ & Rataan \\
\hline $\mathbf{K}_{\mathbf{0}}$ & 34.93 & 37.67 & 39.00 & 37.20 \\
$\mathbf{K}_{\mathbf{1}}$ & 38.67 & 38.67 & 38.67 & 38.67 \\
$\mathbf{K}_{\mathbf{2}}$ & 37.67 & 38.33 & 37.67 & 37.89 \\
$\mathbf{K}_{\mathbf{3}}$ & 37.33 & 38.87 & 41.53 & 39.24 \\
\hline Rataan & 37.15 & 38.38 & 39.22 & $\mathrm{KK}=6.13 \%$ \\
\hline
\end{tabular}

Keterangan : Angka-angka yang diikuti oleh huruf yang sama pada kolom yang sama untuk setiap perlakuan tidak berbeda nyata menurut uji duncan pada taraf $5 \%$.

Dari Tabel 3 dapat dilihat bahwa pemberian pupuk NPK Yara-Mila 16-1616 dengan perlakuan 86,4 g/plot $\left(\mathrm{Y}_{2}\right)$ memiliki umur berbunga terlama yaitu pada 39,22 (hari) dan perlakuan $0 \mathrm{~g} /$ plot $\left(\mathrm{Y}_{0}\right)$ memiliki umur berbunga tercepat yaitu pada 37,15 (hari). Sedangkan pemberian pupuk kandang kotoran sapi dengan perlakuan $5,76 \mathrm{~kg} / \mathrm{plot}\left(\mathrm{K}_{3}\right)$ memiliki umur berbunga terlama yaitu pada 39,24 (hari) dan perlakuan $0 \mathrm{~kg} /$ plot $\left(\mathrm{K}_{0}\right)$ memiliki umur berbunga tercepat yaitu pada 37,20 (hari) setelah tanam.

Tidak berpengaruhnya pupuk organik (kotoran sapi) terhadap parameter umur berbunga tanaman disebabkan oleh karena kandungan hara pada pupuk organik umumnya rendah dan lambat tersedia, tanaman tidak dapat menyerap unsur hara yang terkandung di dalamnya, sehingga unsur tersebut tidak mampu menyuplai kebutuhan hara untuk pertumbuhan tanaman kacang panjang hingga masa panen. Selain itu juga karena pupuk organik yang diaplikasikan pada tanah belum dapat diproses oleh tanah dan tanaman, karena harus melalui tahapan mineralisasi agar bahan organik dapat melepaskan sejumlah unsur hara yang dibutuhkan tanaman. Hal ini didukung oleh pendapat Hartatik dkk (2015), yang menyatakan bahwa kadar hara dalam pupuk organik relatif rendah dan sangat bervariasi, sehingga manfaatnya bagi tanaman berlangsung dalam jangka panjang. Pupuk organik memiliki kandungan hara yang rendah, maka bahan/pupuk organik memerlukan 12-25 kali lebih berat atau lebih banyak untuk menyediakan hara yang sama jumlahnya dengan hara yang disediakan dari pupuk kimia buatan. Hasil - hasil penelitian aplikasi pupuk kandang kotoran sapi yang dikombinasikan dengan pupuk anorganik dapat meningkatkan efisiensi penggunaan pupuk organik dalam kisaran $2-20 \%$.

Adanya pengaruh interaksi yang tidak nyata terhadap parameter umur berbunga tanaman menunjukkan bahwa kedua faktor tidak dapat saling mempengaruhi satu sama lainnya. Kedua faktor perlakuan tersebut hanya menunjukkan pengaruhnya masing-masing secara tunggal.

Dari hasil analisis pengamatan dan analisis sidik ragam dapat dilihat bahwa pemberian pupuk kandang kotoran sapi maupun pupuk NPK Yara-Mila 16-16-16 menunjukkan tidak berpengaruh nyata terhadap produksi per tanaman sampel tanaman kacang panjang. Sama halnya dengan interaksi antara pemberian pupuk kandang kotoran sapi dan pupuk NPK Yara-Mila 16-16-16 juga menunjukkan tidak berpengaruh nyata terhadap produksi per tanaman sampel tanaman kacang panjang. 
Tabel 4. Hasil Uji Beda Rataan Pengaruh Pemberian Pupuk Kandang Kotoran Sapi dan Pupuk NPK Yara-Mila 16-16-16 Terhadap Produksi per Tanaman Sampel Tanaman Kacang Panjang.

\begin{tabular}{ccccc}
\hline Perlakuan & $\mathbf{Y}_{\mathbf{0}}$ & $\mathbf{Y}_{\mathbf{1}}$ & $\mathbf{Y}_{\mathbf{2}}$ & Rataan \\
\hline $\mathbf{K}_{\mathbf{0}}$ & 116,13 & 127,40 & 133.17 & 125,57 \\
$\mathbf{K}_{\mathbf{1}}$ & 121,29 & 128,04 & 12,66 & 125,13 \\
$\mathbf{K}_{\mathbf{2}}$ & 122,33 & 128,04 & 10,74 & 119,27 \\
$\mathbf{K}_{\mathbf{3}}$ & 121,33 & 128,41 & 136,03 & 128,59 \\
\hline Rataan & 120,27 & 127,98 & 125,68 & $\mathrm{KK}=13,12 \%$ \\
\hline
\end{tabular}

Keterangan : Angka-angka yang diikuti oleh huruf yang sama pada kolom yang sama untuk setiap perlakuan tidak berbeda nyata menurut uji duncan pada taraf $5 \%$.

Dari Tabel 4 dapat dilihat bahwa pemberian pupuk NPK Yara-Mila 16-1616 dengan perlakuan 43,2 g/plot $\left(\mathrm{Y}_{1}\right)$ memiliki produksi per tanaman sampel tertinggi yaitu 127,98 gram, dan perlakuan $0 \mathrm{~g} /$ plot $\left(\mathrm{Y}_{0}\right)$ memiliki produksi per tanaman sampel terendah yaitu 120,27 gram. Sedangkan perlakuan pemberian pupuk kandang kotoran sapi dengan perlakuan 5,76 $\mathrm{kg} /$ plot $\left(\mathrm{K}_{3}\right)$ memiliki produksi per tanaman sampel tertinggi yaitu 128,59 gram, dan perlakuan $0 \mathrm{~kg} /$ plot $\left(\mathrm{K}_{0}\right)$ memiliki produksi per tanaman sampel terendah yaitu 125,57 gram.

Secara statistik perlakuan pupuk kandang kotoran sapi tidak memberikan hasil yang nyata, tetapi ada tendensi bahwa semakin meningkat dosis pupuk organik yang diberikan dan waktu pemberian minimal 1 (satu) bulan sebelum tanam, maka semakin meningkat pula pertumbuhan tanaman, baik pertumbukan vegetatif maupun generatif. Hal ini dikarenakan pemberian pupuk kandang kotoran sapi pada tanah mampu memperbaiki kondisi lingkungan bagi pertumbuhan tanaman. Sebagaimana dikatakan oleh Safei et al (2014), bahwa pengembalian bahan organik ke dalam tanah dapat mempertahankan lahan agar tetap produktif, karena bahan organik selain dapat menambah unsur hara juga dapat meningkatkan kandungan bahan organik tanah yang penting dalam memperbaiki sifat tanah baik secara fisik, kimia dan biologi.

Begitu juga dengan perlakuan pemberian pupuk NPK Yara-Mila, dimana secara statistik tidak memberikan hasil yang nyata, tetapi ada tendensi bahwa semakin meningkat dosis pupuk NPK Yara-Mila yang diberikan maka semakin meningkat pula produksi per tanaman sampel, dibandingkan dengan perlakuan tanpa pupuk NPK Yara-Mila. Keadaan ini disebabkan dengan pemberian pupuk NPK Yara-Mila dapat meningkatkan ketersediaan unsur hara $\mathrm{N}, \mathrm{P}$, dan $\mathrm{K}$. Semakin banyak unsur hara yang tersedia dapat meningkatkan serapan unsur hara oleh tanaman kacang panjang, yang akhirnya dapat meningkatkan produksi menjadi lebih baik.

Adanya pengaruh yang tidak nyata terhadap parameter produksi per tanaman sampel menunjukkan bahwa tidak adanya interaksi antara pupuk kandang kotoran sapi dan pupuk NPK Yara-Mila 16-16-16 yang disebabkan karena kedua faktor tidak dapat saling mempengaruhi satu sama lainnya. Kedua faktor perlakuan tersebut hanya menunjukkan pengaruhnya masingmasing secara tunggal.

Dari hasil analisis pengamatan dan analisis sidik ragam dapat dilihat bahwa pemberian pupuk kandang kotoran sapi menunjukkan pengaruh sangat nyata terhadap produksi tanaman per plot. Sedangkan pemberian pupuk NPK YaraMila 16-16-16 menunjukkan tidak berpengaruh nyata terhadap produksi tanaman per plot. Interaksi antara pemberian pupuk kandang kotoran sapi dan pupuk Yara-Mila 16-16-16 juga menunjukkan tidak berpengaruh nyata terhadap produksi per plot tanaman kacang panjang. 
Tabel 5. Hasil Uji Beda Rataan Pengaruh Pemberian Pupuk Kandang Kotoran Sapi dan Pupuk NPK Yara-Mila 16-16-16 Terhadap Produksi per Plot Tanaman Kacang Panjang.

\begin{tabular}{ccccc}
\hline Perlakuan & $\mathbf{Y}_{\mathbf{0}}$ & $\mathbf{Y}_{\mathbf{1}}$ & $\mathbf{Y}_{\mathbf{2}}$ & Rataan \\
\hline $\mathbf{K}_{\mathbf{0}}$ & 1,87 & 1,92 & 1,97 & $1,92 \mathrm{~b}$ \\
$\mathbf{K}_{\mathbf{1}}$ & 1,84 & 2,28 & 2,28 & $2,13 \mathrm{a}$ \\
$\mathbf{K}_{\mathbf{2}}$ & 2,55 & 2,39 & 2,83 & $2,59 \mathrm{a}$ \\
$\mathbf{K}_{\mathbf{3}}$ & 3,08 & 2,64 & 3,19 & $2,97 \mathrm{a}$ \\
\hline Rataan & 2,34 & 2,31 & 2,56 & $\mathrm{KK}=14,71 \%$ \\
\hline
\end{tabular}

Keterangan : Angka-angka yang diikuti oleh huruf yang sama pada kolom yang sama untuk setiap perlakuan tidak berbeda nyata menurut uji duncan pada taraf $5 \%$.

Dari Tabel 5 dapat dilihat bahwa pemberian pupuk kandang kotoran sapi dengan perlakuan $5,76 \mathrm{~kg} / \mathrm{plot} \quad\left(\mathrm{K}_{3}\right)$ memiliki produksi per plot tertinggi yaitu $2,97 \mathrm{~kg}$, dan perlakuan $0 \mathrm{~kg} / \mathrm{plot}\left(\mathrm{K}_{0}\right)$ memiliki produksi per plot terendah yaitu $1,92 \mathrm{~kg}$. Menurut Oktavianti $d k k$ (2017), bahwa pupuk organik kandang sapi memiliki sifat yang dapat memperbaiki sifat biologi dan fisika tanah, sehingga dapat membantu kegiatan akar dalam melakukan pengangkutan air ke dalam tanaman. Selain itu, keunggulan pupuk kandang sapi bagi tanah yaitu dapat meningkatkan meningkatkan porositas tanah untuk menahan air dan oksigen yang lebih banyak. Karena adanya kemampuan untuk menahan air, maka akar tanaman dapat lebih mudah dan lebih banyak menyerap air yang berpengaruh pada bobot basah dan kering polong kacang panjang. Hal ini berarti pemberian pupuk kandang kotoran sapi memberikan pengaruh nyata terhadap hasil produksi tanaman.

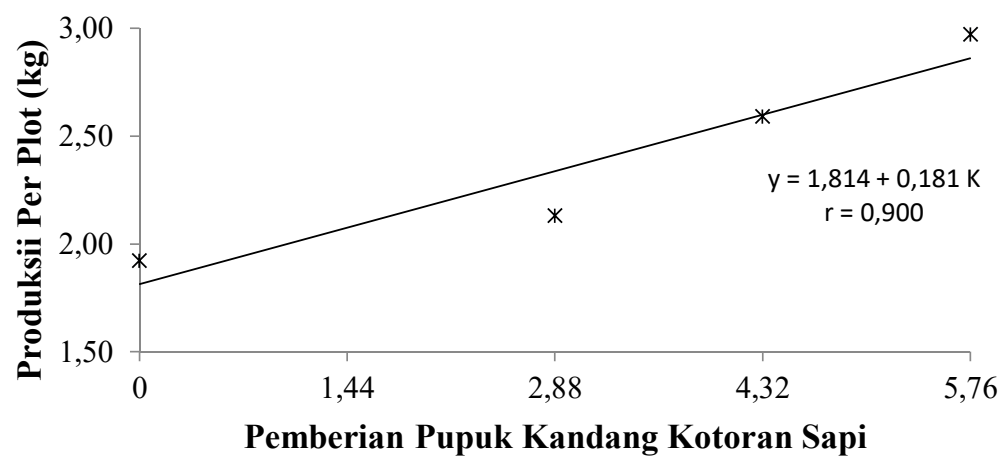

Gambar 5. Pengaruh Pemberian Pupuk Kandang Kotoran Sapi Terhadap Produksi Per Plot Tanaman Kacang Panjang

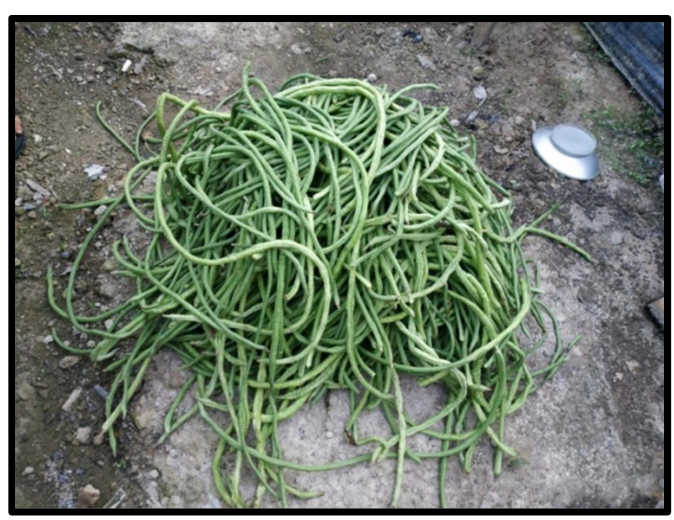

Gambar 6. Pengamatan Parameter Produksi Per Plot Tanaman Kacang Panjang
Berdasarkan hasil penelitian, pemberian pupuk kandang kotoran sapi secara nyata dapat meningkatkan produksi per plot tanaman kacang panjang. Hal ini dikarenakan pemberian pupuk kandang kotoran sapi dapat memenuhi kebutuhan unsur hara $\mathrm{N}, \mathrm{P}$, dan $\mathrm{K}$ serta unsur mikro tanaman kacang panjang. Seperti dikemukakan oleh Wijaya (2018), bahwa apabila menambahkan suplai hara yang cukup, maka akan membantu terjadinya proses fotosintesis dalam tanaman untuk menghasilkan senyawa organik yang akan diubah dalam bentuk ATP saat 
berlangsungnya respirasi. Selanjutnya ATP ini digunakan untuk membantu pertumbuhan tanaman. Selama pertumbuhan reproduktif akan terjadi pemacuan pembentukan bunga, polong serta biji kacang panjang. Maka dengan cukupnya kebutuhan hara tanaman baik unsur makro maupun mikro, akan membantu metabolisme tanaman berjalan lancar, selanjutnya akan berguna dalam memacu pertumbuhan tanaman baik vegetatif maupun generatif.

Tidak adanya pengaruh yang nyata terhadap produksi per plot tanaman kacang panjang menunjukkan bahwa interaksi antara pemberian pupuk kandang kotoran sapi dan pupuk NPK Yara-Mila belum mampu mempengaruhi pola aktivitas fisiologi tanaman secara interval, walaupun diantara perlakuan yang diuji telah mampu mendukung pertumbuhan tanaman secara fisiologi.

Dalam hal lain mungkin faktor luar dari tanaman itu sendiri kurang mendukung aktivitas dari kedua perlakuan, sebab kombinasi dari kedua perlakuan tertentu tidak selamanya akan memberikan pengaruh yang baik pada tanaman. Ada kalanya kombinasi tersebut akan mendorong pertumbuhan tanaman, menghambat pertumbuhan atau sama sekali tidak memberikan respon terhadap pertumbuhan dan perkembangan tanaman.

Hal ini sesuai dengan pendapat Lingga dan Marsono (2003) dalam Fajri et al., (2020), yang menyatakan bahwa untuk respon pupuk yang diberikan sangat ditentukan oleh berbagai faktor antara lain sifat genetis dari tanaman, iklim, tanah, dimana faktor-faktor tersebut tidak berdiri sendiri melainkan faktor yang satu berkaitan dengan faktor yang lainnya. Sutedjo (2002) dalam Fajri et al., (2020), juga menyatakan bahwa bila salah satu faktor lebih kuat pengaruhnya terhadap faktor lain, maka faktor lain akan tertutup dan masing-masing faktor mempunyai sifat dan cara kerja yang berbeda, yang akan menghasilkan hubungan yang tidak berbeda nyata untuk mendukung suatu pertumbuhan tanaman. Hal ini juga disebabkan karena tanah memberikan pengaruh bagi kelangsungan pertumbuhan tanaman. Pengaruh tersebut antara lain temperatur tanah, kelembaban tanah, permeabilitas, tersedianya unsur hara, kegiatan hidup jasad renik dan banyak sifat tanah lainnya.

Kemungkinan lain yang menyebabkan tidak adanya pengaruh yang nyata terhadap parameter yang diamati, diduga interaksi kedua perlakuan kurang saling mendukung satu sama lainnya, sehingga efeknya akar tanaman tidak respon. Dengan kata lain, dua faktor perlakuan dikatakan berinteraksi apabila pengaruh suatu faktor perlakuan berubah pada saat perubahan taraf faktor perlakuan lainnya. Tetapi apabila pengaruh interaksi tidak berbeda nyata, maka disimpulkan bahwa diantara faktor-faktor perlakuan tersebut bertindak bebas atau pengaruhnya berdiri sendiri. Hal ini sesuai dengan pendapat Fajri et al., (2020), yang menyatakan bahwa pertumbuhan tanaman yang baik dapat tercapai bila faktor yang mempengaruhi pertumbuhan bersimbang dan menguntungkan.

\section{KESIMPULAN}

1. Perlakuan pemberian pupuk kandang kotoran sapi berpengaruh nyata terhadap jumlah daun umur 2 MST dan berpengaruh sangat nyata terhadap tinggi tanaman umur 2, 4 dan 6 MST, dan produksi per plot. Jumlah daun terbanyak umur 2 MST adalah 8.44 helai pada perlakuan $\mathrm{K}_{3}$. Tinggi tanaman yang tertinggi umur 6 MST adalah $230.87 \mathrm{~cm}$ pada perlakuan $\mathrm{K}_{3}$. Produksi per plot terberat adalah $2.97 \mathrm{~kg}$ pada perlakuan $\mathrm{K}_{3}$.

2. Perlakuan pemberian pupuk NPK Yara-Mila 16-16-16 berpengaruh nyata terhadap tinggi tanaman umur 4 dan 6 MST. Tinggi tanaman yang tertinggi umur 6 MST adalah 218.64 cm pada perlakuan $\mathrm{Y}_{2}$.

3. Interaksi antara pemberian pupuk kandang kotoran sapi dan pupuk 
NPK Yara-Mila 16-16-16 berpengaruh nyata terhadap jumlah daun umur 4 MST. Jumlah daun terbanyak umur 4 MST adalah 16.93 helai pada perlakuan $\mathrm{K}_{1} \mathrm{Y}_{1}$.

\section{SARAN}

Diperlukan penelitian lanjutan dengan menggunakan dosis atau jumlah pupuk yang berbeda dan lokasi penelitian yang berbeda, sehingga dapat diketahui perbandingan dari iklim suatu daerah dan efektivitas pemupukan terhadap pertumbuhan dan produksi tanaman kacang panjang.

\section{DAFTAR PUSTAKA}

Anonim. 2011. Cekaman Unsur Hara Kalium Terhadap Fisiologi Tanaman.

http://translate.google.co.id/translat $\mathrm{e} ? \mathrm{hl}=\mathrm{id} \&$ langpair $=\mathrm{en} \mid \mathrm{id} \& \mathrm{u}=\mathrm{http}: / / 4$ e.plantphys.net/article.php $\% 3 \mathrm{Fch} \%$ 3D3\%26id\%3D289. Di akses pada tanggal 09-02-2020.

Arniana, A. 2012. Pemanfaatan Residu Bahan Organik Dan Fosfor Untuk Budidaya Tanaman Kacang Panjang (Vigna sinensis L.). Berkala Penelitian Argonomi Vol 1: 8-15.

BPS. 2014. Standarisasi Mutu Sayuran Dataran Rendah. Balai Penelitian. Jawa Barat.

Fahmi, N. 2014. Pengaruh Pupuk Organik Dan Anorganik Terhadap Pertumbuhan Dan Hasil Kedelai (Glycine max (L.) merril). Jurnal Floratek 9: 53-62.

Fajri, S., Ranadhan, A. 2020. Respon Pemberian Pupuk Kompos Tandan Kosong Kelapa Sawit Dan Pupuk Kalium Terhadap Pertumbuhan Dan Produksi Tanaman Jagung (Zea mays L.) Baby Corn. Jurna
Pionir LPPM Vol. 6 No. 1 Januari2020. Universitas Asahan.

Hartatik, W., Husnain., Widowati, L. 2015. Peranan Pupuk Organik Dalam Peningkatan Produktivitas Tanah Dan Tanaman. Makalah. Balai Penelitian Tanah. Bogor.

Hendri, M. 2015. Pengaruh Pupuk Kandang Sapi Dan Pupuk NPK Mutiara Terhadap Pertumbuhan Dan Hasil Tanaman Terung Ungu (Solanum melongena L.). Jurnal Agrivor Vol 14 (2).

Jamin., Lun Kai., Mohamad Ikbal Bahua.. Fitria, S. 2013. Pertumbuhan Dan Produksi Kacang Hijau (Vigna radiata) Melalui Pemberian Pupuk Organik Kotoran Sapi.

Nurhayati. 2010. Pemanfaatan Lahan Pertanian Untuk Tanaman Pangan. Penebar Swadaya. Jakarta.

Nurnik. 2012. Manfaat Dari pupuk NPK Mutiara dan Granul. Penelitihan UGM. Yogyakarta.

Oktavianti, A., Izzati, M., Parman, S. 2017. Pengaruh Pupuk Kandang Dan Pupuk NPK Mutiara Terhadap Pertumbuhan Dan Produksi Kacang Panjang (Vigna sinensis L.) Pada Tanah Berpasir. Buletin Anatomi Dan Fisiologi Vol.2 No.2 Agustus2017. Universitas Diponegoro.

Safei, Muhammad., Abdul Rahmi, dan Noor Jannah. 2014. Pengaruh Jenis Dan Dosis Pupuk Organik Terhadap Pertumbuhan Dan Hasil Tanaman Terung (Solanum melongena L.) Varietas Mustang F1. Agroteknologi, Fakultas Pertanian, Universitas 17 Agustus 1945 Samarinda, Indonesia. Jurnal AGRIFOR Volume XIII Nomor 1, Maret 2014 ISSN : $1412-6885$. 
Thomas, W., Tobing, O, L., Rochman, N. 2017. Pengaruh Pupuk Kandang Dan Dolomit Terhadap Pertumbuhan Dan Produksi Tanaman Kacang Panjang (Vigna sinensis L.). Jurnal Agronida Vol. 3 No.1 April - 2017.

Wijaya, A., K. 2018. Pengaruh Penggunaan Pupuk Kompos Terhadap Pertumbuhan Dan Hasil Benih Kacang Panjang (Vigna sinensis L.) di Subak Basang Be. Program Studi Agroekoteknologi, Fakultas Pertanian. Universitas Udayana. Denpasar. 